\title{
Legal Covariance Model: Volkgeist-Based Legal Learning Design in Civic Education in the New Normal Era
}

\author{
Dadang Sundawa ${ }^{1}$, Dwi Iman Muthaqin ${ }^{2 *}$, Kanigara Hawari ${ }^{3}$, Baeihaqi Baeihaqi ${ }^{4}$ \\ 1,2,3,4 Universitas Pendidikan Indonesia, Bandung, Indonesia \\ ${ }^{*}$ Corresponding author.Email: dwiimanm@upi.edu
}

\begin{abstract}
Legal education as a body of knowlagde of civic education plays an important role in community development. This is because the law forms habits in the community. In the new normal era, the development of legal awareness is carried out online/blended learning. The reason is the situation and condition of the Covid-19 pandemic. However, the implementation of education must still be implemented. Likewise with legal education in developing legal awareness. This is because considering the importance of building legal awareness which is the basis for the purpose of the presence of law in society. The orientation is to create a harmonious life so that each individual can live in an orderly and peaceful manner. In developing legal awareness in the new normal era, a procedure is needed that is designed as a guide in legal education for the development of legal awareness. The legal covariance model is a learning model designed to develop legal awareness, because it is designed to make Pancasila the basis for public legal awareness based on the nature of Pancasila as a volkgeist. This model has five, namely problem orientation, organizing learning situations, monitoring progress, presenting results and discussions, and evaluation. Through these stages, this model acts as a legal learning guide with the aim of building legal awareness, and the placement of Pancasila as a volkgeist oriented as a preventive instrument in the context of ethics and morals to encourage the process of building legal awareness by exploring living law.
\end{abstract}

Keywords: Civic Education, Legal Covariance Model, Legal Education, Volkgeist.

\section{INTRODUCTION}

COVID-19 is currently a global-scale disaster phenomenon that has become a deadly disease outbreak with a relatively fast spread of the virus throughout the world. COVID-19 has also been declared by the World Health Organization (WHO) as a pandemic [1]. The implications of this pandemic have created a Public Health Emergency, which must be taken care of in accordance with the provisions of laws and regulations, as regulated in Law Number 6 of 2018 concerning Health Quarantine as an effort to prevent the spread of COVID19. The current state of the Coronavirus Disease 2019 (COVID-19) pandemic has implications for the learning process that must be carried out online or in blended learning. This is done to stop the spread of the virus that continues to occur, so that the learning process is carried out by utilizing various technological devices that support the teaching and learning process. This presents its own challenges, especially in designing legal education as one of the content substances in civic education. This is because, non-formal legal education is integrated in the conception of civic education. The implication is that in a more specific context the pattern of legal education in Indonesia does not pay attention to the pattern of active and progressive legal development for all components of society.

This issue was also criticized those various legal educational institutions only focus on preparing law graduates to become government administration officials, judicial officials, and advocates [2]. This shows a pattern of legal education that is not active and progressive in legal development in society. Good legal education is not only based in the realm of learning (law in the books), but also in application (law in the action) [3]. This means that in the implementation of legal education, it should provide a sensory and non-sensory experience to students of the law, the experience that is captured by the senses of students is then absorbed and then converted in the form of values that are engraved in their minds and hearts. As the final form of the educational process is the embodiment of these values into a form of behavior that reflects a conscious attitude of law.

Legal awareness is highly demanded of its presence in society in enforcing the law, because without it there will be no legal certainty and will have implications for a lawless situation. Without the law, of course, the life of society will fall apart where each 
individual is free to act according to his own wishes without regard to the rights of others. This has been alluded to by Hobbes who calls humans homo homony lupus, namely humans who become wolves for other humans. This means that in essence humans will oppress other people who have degrees and powers lower than themselves, therefore we need a set of rules that can limit human movement so as not to oppress the rights of other humans. This certainly refers to the importance of developing a law-conscious character. The urgency of fostering a litigious character is basically based on the purpose of the presence of law in people's lives, namely to create a harmonious life where each individual can live in an orderly and peaceful manner [4].

The development of legal awareness, of course, must be based on the basis of the state, namely Pancasila so that it does not come out of the identity of the Indonesian nation as a civilized nation. The Legal Covariance model is oriented to the design of legal education in citizenship education based on Pancasila as a volkgeist to develop legal awareness. This is intended to foster legal awareness of students in the classroom. This learning model is designed to make Pancasila the basis of public legal awareness based on the nature of Pancasila as a volkgeist, namely as a set of value systems within the framework of the life of the nation and state of the Indonesian people which is explored according to the ideals, culture and life of the Indonesian nation [5]. The Legal Covariance learning model places Pancasila as a preventive instrument for the Indonesian nation in the context of ethics and morals to encourage the process of building legal awareness by exploring the noble values of the Indonesian people who live in various norms and values that live in society (living law).

\section{LEGAL EDUCATION AS A BODY KNOWLADGE OF CIVIC EDUCATION}

Formal legal education is basically classified into two, namely (1) carried out in Pancasila and Civic education at the basic education, secondary education and higher education non-law faculties, and (2) carried out at the Faculty of Law, with the orientation to form a legal expert (legal). Meanwhile, non-formal legal education can be obtained through knowledge that is independently studied by everyone or through legal counseling or providing information that can provide legal understanding to the public.

The integration of legal education in Civic Education is basically because it is a multidisciplinary discipline and includes studies related to political education, legal education and values education as its mission, as well as state defense education [6], [7]. Civic Education also has a role in building legal awareness, but in some countries, what is meant is law education, street law education, and not civic education. The difference is because in each country the legal education that is carried out is different, but in Indonesia legal education is integrated in Civic Education [8]. The statement identifies that Civics has a body of knowledge that includes politics, law as well as values and morals that are integrated with each other in supporting the formation of good and intelligent citizens' character.

The position of Civic Education as legal education is also stated in the International Commission of Jurist, which at the conference of international organizations of legal experts held in Bangkok in 1965 described the conditions for democratic government under the rule of law, namely: "(1). Constitutional protection, in the sense that the constitution in addition to guaranteeing individual rights, must also determine the procedural way to obtain the protection of guaranteed rights; (2) independent and impartial tribunals; (3). Free elections; (4) Freedom of expression; (5). Freedom of association for association/organization and opposition; and (6). Civic Education/Citizenship Education" [9]. Legal education is also intended as part of education for citizens. Education for citizens is expressed in three phrases, namely: "civic education" "citizenship education" or "public education". In the context of the position of Civic Education as legal education, it means that Civics is legal education in a constitutional democracy or a democracy based on law [10].

The function of legal education in Civic Education is basically directed to the ability to maintain values that are considered good by the community, because the function of law itself is to maintain public order. In this context, of course, the basic values that make up the law must be based on religious values, and the socio-cultural values of the community, so that they can represent rules or regulations that are in accordance with the socio-cultural conditions of the community. Presence of law is to uphold the values of society and is considered as the embodiment of the content of these values [11]. The role of legal education in developing citizenship includes: (1) being interested in legal issues that are currently happening in society, (2) discuss cooperatively with various people to solve legal problems. (3) utilizing views and thoughts on legal matters [10]. This is certainly in line with the mandate of Article 1 Paragraph 2 of the 1945 Constitution of the Republic of Indonesia which contains the principle of a democratic state, namely sovereignty is in the hands of the people, and Article 1 or 3 of the 1945 Constitution of the Republic of Indonesia which expressly states that Indonesia is a state law [12].

Legal education is about developing a more critical and socially responsible awareness of citizenship, and about giving students the skills to make a positive difference in society and the nation [13], [14]. This goal is an integral part of the expectations of educational social studies; that is, preparing our youth for citizenship, developing students' abilities to think critically about an issue, and encouraging students to take action to make the world a better place [15], [16]. Based on this explanation, education that is oriented to the legal internalization process is a must. The realization of this is through legal 
education in Civic Education which acts as a vehicle for developing legal awareness for the younger generation.

\section{PANCASILA AS VOLKGEIST IN LEGAL EDUCATION}

Volkgeist or the soul of the nation is the main idea of Friedrich Carl von Savigny who is a legal expert from Germany. This idea was a reaction to Thibout's efforts to initiate the codification of law in Germany which was influenced by the codification concepts of Justinian and the Code Napoloen. The essence of this idea is that law is not made by humans, but grows, lives and develops in the soul of the nation or (das recht wird nicht gemacht, est ist und wird mit dem volke) based on the assumption that every nation in the world has a volkgeist (soul of the nation) [4]. Terminologically, volksgeist has the same meaning as the word volksseele, nationalgeist, geist der nation, volkscharakter or in English it is called national character which literally means the soul or spirit of the nation [17]. Meanwhile, according to Herder, volksgeist is defined as a manifestation of the spirit of the community and at the same time being the spirit or soul of a nation. Volkgeist is a terminology that means psychology and spirituality which is a unity (inherent) and operates in various entities that manifest (embodiment) in the form of language, folklore, customs, and also legal order [18]. The existence of Pancasila as a volksgeist is in line with Savigny's view which states that legal instruments should grow from the culture, ideals and spirit of a society.

Pancasila values contained in the five precepts have essentially contained the existence of the Indonesian volksgeist. This is evidenced by the existence of various state administration practices that use various habits that are not listed in positive legal regulations or what became known as conventions [5]. In the context of law enforcement, especially in resolving legal disputes that occur in the community, they often use family principles that have long been embraced and believed by the community in the form of norms and culture (living law). The existence of Pancasila as the basis of the state is an accumulation of the spirit of the founding fathers of the nation in knitting and uniting the spirit of the Indonesian nation which spread from Sabang to Merauke which was later designated as Philosopische Grondslag. This is in line with Thibaut's idea that law is a guideline born from a process that departs from within (internally) and is autonomously operating silently (silently) within the soul and spirit of the community. This process begins in a unitary community (nation) based on a commitment to trust and belief as well as the nation's communal awareness [19]. Law is like a language that grows, lives and develops in national relations and becomes a shared property and awareness based on the character and soul of the nation concerned (volksgeist).

Positioning Pancasila as a volkgeist in legal education is an attempt to bring the law closer to society. In social life, a community group has a set of values that are manifested in various norms and habits (living law) which they believe and live voluntarily without any coercion or threat from any party. This happens because the norms and customs they have believed as a truth so that there is no longer any doubt in it. It should be noted that every community group or nation has its own view of life which contains various moral or ethical values which are considered as "truth". The basis for this truth comes from various assumptions about something that is good and bad, something that is considered right or wrong, worthy or unworthy, and something that is considered fair or unfair [20]. These various views are then referred to as values.

Pancasila, apart from being a volkgeist, is also a philosophical philosophy (view of life) of the Indonesian nation. In the context of the national legal system, the presence of Pancasila as a philosophic grondslag is seen as a legal ideal (rechtsidee) which is a guideline for the development of Indonesian law directed at implementing various values, ideas, and ideals contained in Pancasila. In line with that, in Stufenbau Theory Pancasila occupies the position of grundnorm or basic values which means that all laws and regulations in Indonesia adopt the values contained in Pancasila. Whether viewed as philosophic grondslag or grundorm, in essence, the two concepts are in one line that leads to the voilkgeist (soul of the nation). So, by making Pancasila a role model in the legal education process, it will support the realization of public legal awareness.

\section{LEGAL COVARIANCE MODEL IN LEGAL AWARENESS DEVELOPMENT}

The Legal Covariance learning model in principle is a learning model designed to make Pancasila the basis for public legal awareness. This model becomes a learning design in the legal learning process as an effort to realize the development of citizen awareness through the teaching and learning process in the formal education level. This model acts as a legal learning guide with one of its goals being to build legal awareness, and placing Pancasila as a volkgeist oriented as a preventive instrument in the context of ethics and morals to encourage the process of building legal awareness by exploring living law.

Pancasila as a volkgeist is as a set of value systems within the framework of the life of the nation and state of the Indonesian people which is explored according to the ideals, culture and life of the Indonesian nation [5]. This shows that this model in the design of the learning process explicitly places Pancasila as a preventive instrument for the Indonesian nation in the context of ethics and morals to encourage the process of building legal awareness by exploring the noble values of the Indonesian people who live in various norms and values that live in society (living law). The Legal Covariance learning model consists of five stages in the learning syntax which are illustrated as follows: 


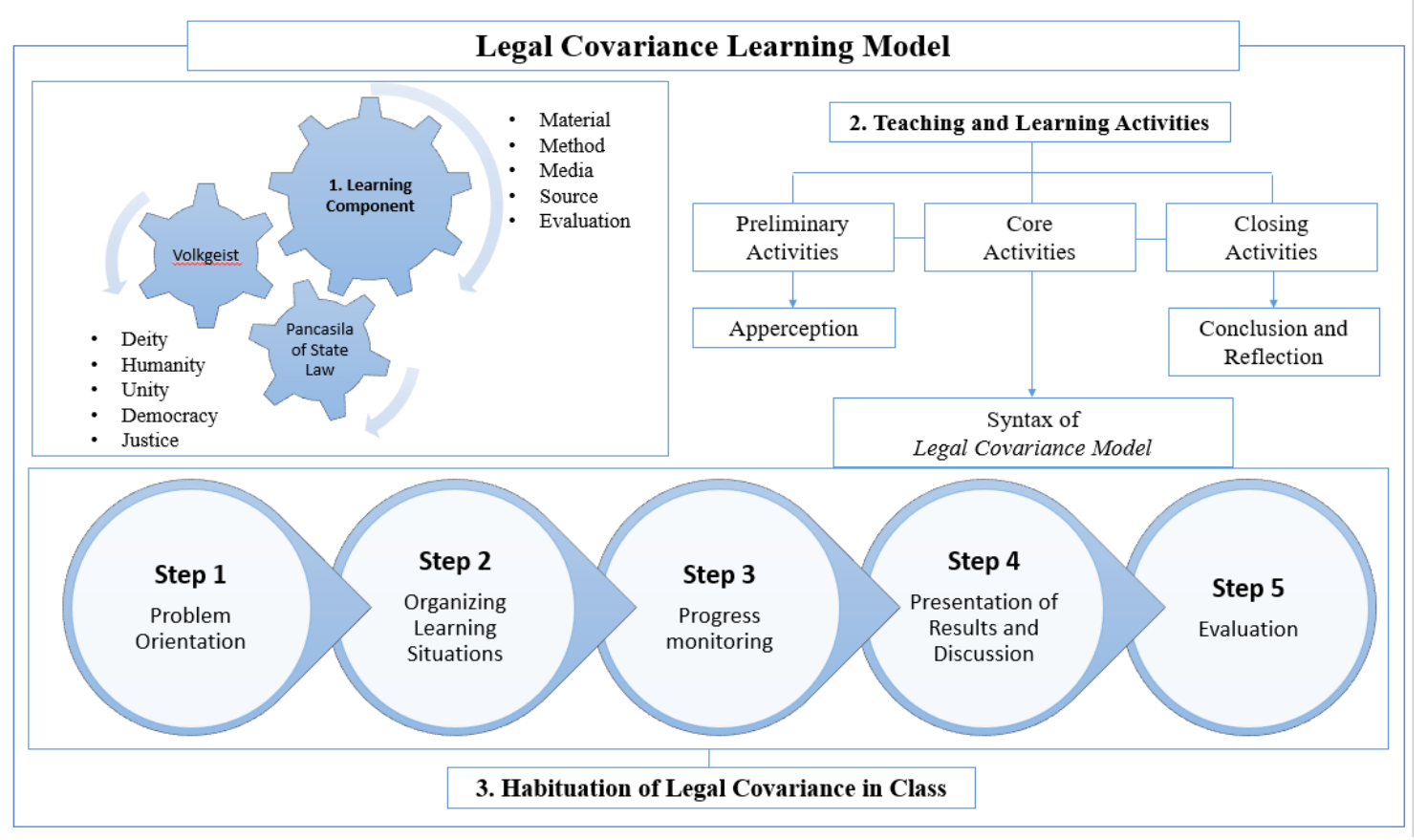

Figure 1. The Legal Covariance Learning Model

The description of the model stages in Figure 1 is described as follows:

1. Problem Orientation, which is a process that contains a series of activities that focus on the introduction of learning content which can be detailed as follows:

a. Explaining the learning objectives related to the material needs of criminal law in crime;

b. Showing videos related to criminal cases;

c. Motivating students to be involved in problem solving activities;

d. Divide students into five discussion groups.

2. Organizing Learning Situations, which is a process that contains a series of activities that focus on preparing students to analyze cases which can be detailed as follows:

a. Helping students define and organize learning tasks related to the problem, namely regarding the need for criminal law in crime;

b. Directing students to find various credible literature sources that can be used as material for problem analysis.

3. Progress Monitoring, which is a process to encourage students to collect appropriate information, namely how Pancasila can be a solution to problems that occur.

4. Presentation of Results and Discussion, which is a process for assisting students in presenting ideas for solutions to problems that are analyzed based on the results of group discussions.

5. Evaluation, which is a process to help students reflect and evaluate the ideas that have been created and presented.

In the process of implementing this model, it must be oriented to the implementation of legal learning in an integrative, interactive and collaborative manner with teacher and media learning patterns as well as media learning patterns in the operation of learning components, both in materials, methods, media, learning resources and learning evaluation by emphasizing on development of legal awareness, as well as the habituation process in the classroom, both online and in blended learning. This is because learning activities are not just teaching that ignores learning activities, and not just preparing teachers and conducting learning according to teaching procedures, but learning activities that are more complex and carried out with varied learning patterns [21]. The statement indicates that the learning process is basically a complex activity and requires the application of varied learning patterns in its implementation, especially in the learning process in the current new normal caused by the situation and conditions of the COVID-19 pandemic so that the learning process is not carried out offline.

The teaching and learning process using this learning model will direct the development of students' legal knowledge and understanding to (1) find out the basis for the application of a law by paying attention to a case of violation or legal action; and (2) understand the reasons why the relevant law is needed. In analyzing the problems presented, students are not only limited to knowing what law applies to the case, but more deeply students can find out why the law must apply. In other words, students are also required to analyze various reasons why a certain law needs to be present in society; and (3) students' understanding of the values of Pancasila, because each component of the problem studied must be based on the philosophical foundation of Pancasila. As is known, that Pancasila is present as the source of all sources of law in Indonesia, which means that all applicable laws and regulations in Indonesia 
originate from the noble values of Pancasila. So, with this learning model, students will be directed to develop legal awareness based on the values of Pancasila.

Legal knowledge itself in principle is a basic element of the structure of legal awareness. Legal awareness must be based on knowledge of what the law is, if someone doesn't know what the law is, of course he can't carry out the law properly, people know that the law is important for the community because it protects the community from various kinds of things that violate the law [22]. The understanding of the law is an important element in the development of legal awareness, because if the community only has legal knowledge, it is not sufficient, an understanding of the applicable law is still needed. Through understanding the law, the public is expected to understand the purpose of the legislation and its benefits for the parties whose lives are regulated by the legislation in question [23]. Based on the explanation above, the Legal Covariance model is conceptually designed as a legal learning model that is oriented towards building legal awareness based on Pancasila as a volkgeist in citizenship education for young citizens. Through the stages of the teaching and learning process using the model becomes a procedural reference in the guidelines for developing legal awareness in legal education.

\section{CONCLUSION}

Conceptually, the Legal Covariance learning model is designed to make Pancasila the basis for public legal awareness based on the nature of Pancasila as a volkgeist. This model was developed with an orientation to develop legal awareness. This model is designed based on learning components which include materials, methods, media, teaching materials, and evaluations that are integrated with Pancasila as a volkgeist oriented as a preventive instrument in the context of ethics and morals to encourage the process of building legal awareness by exploring living law. The development of student legal awareness through the Legal Covariance learning model in legal education in civic education is designed based on the stages which include (1) problem orientation, (2) organizing learning situations, (3) monitoring progress, (4) presenting results and discussions, and (5) evaluation. Through these stages, this model acts as a legal learning guide with one of its objectives being to build legal awareness in citizenship education for young citizens.

\section{REFERENCES}

[1]. Minister of Health Regulation No. 9 of 2020 concerning Guidelines for Large-Scale Social Restrictions

[2]. Kansil, C. S. T. (2013). Pengantar Ilmu Hukum dan Tata Hukum Indonesia. Jakarta: Balai Pustaka.

[3]. Slamet, \& Titon. (2013). Pendidikan Hukum, Ilmu Hukum, dan Penelitian Hukum di Indonesia: Sebuah
Reorientasi. Yogyakarta: Pustaka Pelajar. Yogyakarta: Pustaka Belajar.

[4]. Salman, O. (2018). Filsafat Hukum (Perkembangan \& Dinamika Masalah). Bandung: Refika Aditama.

[5]. Dedihasriadi, L. O., \& Nurcahyo, E. (2020). Pancasila sebagai Volkgeist: Pedoman Penegak Hukum dalam Mewujudkan Integritas Diri dan Keadilan. Jurnal Magister Hukum Udayana (Udayana Master Law Journal), 9(1), 142-152.

[6]. Maftuh, B. \& Sapriya. (2005). Pembelajaran PKn melalui Konsep. Jurnal Civicus, 1, (5), 319-328

[7]. Winarno. (2013). Pembelajaran Pendidikan Kewarganegaraan, Isi Strategi dan Penilaian. Jakarta: Bumi Aksara

[8]. Sapriya. (2007). Peran Pendidikan Kewarganegaraan dalam Membangun Karakter Warga Negara. Jurnal Sekolah Dasar, No. 1, pp 2234 (online). Tersedia: http://jurnal.pdii.lipi.go.id/20 ISSN 1412-565 X admin/jurnal/161072234.pdf diakses [6 Januari 2020]

[9]. Budiardjo, M. (2008). Dasar-dasar Ilmu Politik. Jakarta: PT. Gramedia Pustaka Utama.

[10]. Isoyama, K. (2018a). Practice Of Law-Related Education To Develop Legal Literacy. Resource Material Series, no. 105, pp. 127-134.

[11]. Rahardjo, S. (1981). Hukum dan Masyarakat. Bandung: Angkasa Bandung

[12]. The 1945 Constitution of the Republic of Indonesia

[13].Cassidy. A. 2000. A practical Guide to Information System Strategic Planning, Second Edition.

[14].Cassidy, W. (2004). Don't Forget About Law: A Case For Law-Related Education In Elementary Social Studies. Canadian Social Studies, 39 (1).

[15]. Marker, G. and H. Mehlinger (1992). Social studies. In P. W. Jackson (Ed.) Handbook of Research on Curriculum. New York: Macmillan Publishing Co.

[16]. Newmann, F. M. (1989). Education for Citizen Action: Challenge for Secondary Curriculum. Berkley: McCutchan Publishing Corporation

[17].Batubara, G. T., \& Arifin, F. (2019). Model Pendidikan Hukum dalam Upaya Mewujudkan Kesadaran Hukum Siswa Sejak Dini. Jurnal Litigasi, 20(1), 19-56.

[18].Latipulhayat, A. (2015). Khazanah: Friedrich Karl Von Savigny. Padjadjaran Journal of Law, 2(1), 197-208.

[19].Dewi, C. K., M, R. R., \& Mujib, M. (2018). Pengembangan Alat Evaluasi Menggunakan Aplikasi Kahoot pada Pembelajaran Matematika Kelas X. Indonesian Journal of Science and Mathematics Education, 1(2).

[20]. Gunawan, Y., \& Kristian. (2015). Perkembangan Konsep Negara Hukum dan Negara Hukum Pancasila. Bandung: Refika Aditama.

[21]. Ruhimat, T. (2012). Kurikulum dan Pembelajaran. Jakarta: Rajawali Press.

[22].Soekanto, S. (1982). Kesadaran Hukum dan Kepatuhan Hukum. Jakarta: Rajawali.

[23].Ali, A., \& Haryani, W. (2014). Sosiologi Hukum. Jakarta: Kencana. 